\title{
PERFORMANSI TRAKTOR TANGAN RODA DUA MODIFIKASI MENJADI RODA EMPAT MULTIFUNGSI (PENGOLAHAN DAN PENYIANGAN) UNTUK KACANG TANAH DI KABUPATEN LOMBOK BARAT
}

\section{Performance of Two-Wheel Hand Tractor Modified to Four Wheel Multifunction (Soil Processing and Weeding) for Peanut in West Lombok Regency}

\author{
Zulpayatun $^{1}$, Cahyawan Catur Edi Margana ${ }^{1}$, Guyup Mahardhian Dwi Putra ${ }^{1, *)}$ \\ ${ }^{1}$ Program Studi Teknik Pertanian Fakultas Teknologi Pangan dan Agroindustri \\ Universitas Mataram \\ Email $^{*}$ : guyupmdp@gmail.com
}

Diterima: 1 Januari 2017

Disetujui: 2 Februari 2017

\begin{abstract}
Purpose of this study was to test the performance of multifunctional four-wheel hand tractors through testing on its two functions, as tillage and weeding machine. This research was conducted in the village of Aik Ampat District of West Lombok Gerung using four-wheel hand tractors. The method used was an experimental method that carried out in the field. Measured parameters were the actual field capacity, theoretical field capacity, time losses, efficiency of tillage and weeding by using four variations of speed and three replications for each speed. The results showed that, the lower the speed, the theoretical value of field capacity (Kt) was lower. The actual value of field capacity (Ka) was highest at $6 \mathrm{~km} / \mathrm{h}$ speed of $0.143 \mathrm{ha} / \mathrm{h}$ for 1 plow and $0.113 \mathrm{ha} / \mathrm{h}$ for 3 plows. The highest time losses on the land processing with 3 plows at $4.44 \mathrm{~km} / \mathrm{h}$ speed was $45.57 \%$ and the lowest with 1 plow at $5.29 \mathrm{~km} / \mathrm{h}$ speed was $4.23 \%$. The depth of the highest plow rate at $5.29 \mathrm{~km} / \mathrm{h}$ speed using 3 plow tillage, the lowest was 0,076 m on the left plow and at $6 \mathrm{~km} / \mathrm{h}$ speed was $0,012 \mathrm{~m}$ on the middle plow. Land processing with $6 \mathrm{~km} / \mathrm{h}$ speed has the highest efficiency among other speed, either using 1 plow or 3 plows, respectively $91.74 \%$ and $72.53 \%$. The weeding efficiency, $6 \mathrm{~km} / \mathrm{h}$ speed has the highest efficiency of $92.67 \%$ than other speed.
\end{abstract}

Keywords: efficiency, field capacity, four-wheel hand tractors

\begin{abstract}
ABSTRAK
Tujuan dari penelitian ini adalah untuk melakukan uji performansi traktor tangan roda empat multifungsi melalui pengujian pada dua fungsi, yakni sebagai mesin pengolahan tanah dan penyiangan. Penelitian ini dilaksanakan di Desa Aik Ampat Kecamatan Gerung Kabupaten Lombok Barat dengan menggunakan traktor tangan roda empat. Metode yang digunakan adalah metode eksperimental yang dilakukan di lapangan. Parameter yang diukur adalah kapasitas lapang aktual, kapasitas lapang teorotis, waktu hilang, efisiensi pengolahan tanah, dan efisiensi penyiangan dengan menggunakan empat variasi kecepatan dan tiga kali ulangan untuk tiap kecepatan. Hasil penelitian menunjukkan bahwa, semakin rendah kecepatan, nilai kapasitas lapang teoritis $(\mathrm{Kt})$ semakin rendah. Nilai kapasitas lapang aktual (Ka) tertinggi terdapat pada kecepatan $6 \mathrm{~km} / \mathrm{jam}$, sebesar 0,14312 ha/jam untuk 1 bajak dan 0,11314 ha/jam untuk 3 bajak. Waktu hilang tertinggi pada pengolahan
\end{abstract}


tanah dengan 3 bajak pada kecepatan 4,44 km/jam sebesar 45,57 \% dan terendah dengan satu bajak pada kecepatan $5,29 \mathrm{~km} / \mathrm{jam}$ yaitu $4,23 \%$. Kedalaman pembajakan tertinggi pada kecepatan $5,29 \mathrm{~km} / \mathrm{jam}$ pengolahan tanah dengan tiga bajak yaitu pada pada bajak sebelah kiri sebesar 0,076 m dan terendah pada kecepatan $6 \mathrm{~km} / \mathrm{jam}$ pada bajak tengah sebesar 0,012 m. Pengolahan tanah dengan kecepatan $6 \mathrm{~km} / \mathrm{jam}$ memiliki efisiensi yang paling tinggi diantara kecepatan lainnya baik pengolahan tanah dengan satu bajak maupun tiga bajak masing-masing sebesar $91,74 \%$ dan $72,53 \%$. Pada efisiensi penyiangan, kecepatan $6 \mathrm{~km} / \mathrm{jam}$ memiliki efisiensi penyiangan paling tinggi dibandingkan kecepatan yang lain yaitu sebesar $92,67 \%$.

Kata kunci: efisiensi, kapasitas lapang, traktor tangan.

\section{PENDAHULUAN}

\section{Komoditi tanaman pangan} memiliki peranan utama sebagai pemenuh kebutuhan pangan, pakan, dan industri, yang setiap tahunnya cendrung meningkat seiring dengan pertumbuhan penduduk dan berkembangnya industri pangan dan pakan. Sehingga dari sisi Ketahanan Pangan Nasional mempunyai fungsi penting dan strategis.

Salah satu komoditi tanaman pangan yang memiliki peranan penting adalah kacang tanah. Kacang tanah memiliki peran yang cukup besar terutama untuk memenuhi kebutuhan protein, bahan baku industri pangan olahan dan pakan selain kedelai.

Komoditas kacang tanah memegang peranan penting sebagai sumber pendapatan bagi petani di Indonesia. Akan tetapi peningkatan produksi kacang tanah saat ini tidak diikuti oleh perbaikan kualitas (mutu). Penurunan kualitas kacang tanah ini dikarenakan teknologi budidaya dan penanganan pasca panen yang kurang tepat, sehingga kacang tanah lebih mudah terkontaminasi penyakit dan serangan mikroorganisme (Andrianto dkk, 2004).

Pengkajian tentang teknologi
budidaya produksi kacang tanah, menyangkut mekanisasi pertanian juga merupakan salah satu hal yang di-support demi peningkatan produksi pertanian. Walaupun mekanisasi pertanian telah diintroduksikan secara intensif, efektifitas dan perkembangannya masih dirasa sangat lambat. Dibandingkan dengan sebagian besar Negara Asia lainya, perkembangan mekanisasi pertanian di tanah air masih relatif tertinggal (Akbar dkk, 2004). Pada kondisi dimana sumber tenaga manusia di sektor pertanian semakin berkurang, peran tenaga mekanis (traktor) dalam pengolahan tanah sangat membantu dalam meningkatkan produktivitas lahan, serta pola penanaman sesuai dengan jadwal tanam dapat terpenuhi (Akbar dkk, 2004).

Pengkajian tentang teknologi budidaya kacang tanah menyangkut mekanisasi pertanian saat ini sedang dikembangkan dan sudah diaplikasikan, yaitu sebagai pengolahan tanah dan alat penyiangan gulma untuk tanaman kacang tanah menggunakan inovasi teknologi traktor tangan roda dua.

Sebagai alat pengolahan tanah, traktor tangan memiliki daya adaptasi yang tinggi dengan kondisi alam Indonesia. Dilihat dari segi teknis, penggunaan garu dan cangkul untuk alat pengolahan memberikan kapasitas kerja dan tingkat kenyamanaan kerja sangat rendah dibandingkan dengan penggunaan traktor tangan (Santoso dkk, 2007).

Produktifitas traktor tangan roda dua masih sangat kecil dibandingkan dengan traktor roda empat (Santoso dkk, 2007), sehingga saat ini sudah dikembangkan traktor tangan roda dua menjadi roda empat sebagai alat pengolahan tanah, alat penyiangan gulma dan pemanenan kacang tanah agar diperoleh traktor tangan dengan stabilitas 
yang lebih baik, lebih ergonomis, serta pengoperasian alat yang lebih baik.

Berdasarkan uraian diatas telah dilakukan penelitian yang berjudul "Performansi Traktor Tangan Roda Dua Modifikasi Menjadi Roda Empat Multifungsi (Pengolahan Dan Penyiangan) untuk Kacang Tanah Di Desa Aik Ampat Kecematan Gerung Kabupaten Lombok Barat".

\section{METODOLOGI PENELITIAN}

\section{Bahan}

Bahan-bahan yang digunakan dalam penelitian ini adalah lahan olahan dengan luas 0,0011 ha.

\section{Alat}

Alat-alat yang digunakan dalam penelitian ini adalah satu set peralatan perbengkelan, traktor tangan roda empat, bajak singkal, meteran, dan stopwatch.

\section{Prosedur Penelitian}

\section{Persiapan penelitian}

Persiapan meliputi observasi lahan, penyediaan dan pengecekan alat dan bahan, konsultasi teknis dan pengarahan terhadap metode pengoprasian traktor tangan roda empat, dan penentuan pola pengolahan tanah.

\section{Pengambilan data}

Uji kinerja traktor tangan roda empat dilakukan di lahan dengan melakukan pengamatan indikator yang akan diukur sebagai berikut: kecepatan teoritis traktor, panjang lintasan, waktu berjalan maju, waktu belok, lebar bajak, kedalaman pembajakan, putaran roda dan efektivitas pengendalian gulma.

\section{Analisis Data}

Data yang diperoleh pada penelitian ini akan dianalisis menggunakan pendekatan matematis untuk mendapatkan nilai-nilai dan data-data tambahan yang diperlukan dengan menggunakan persamaan matematis. Untuk mempermudah perhitungan yang dipakai dapat diselesaikan dengan program menggunakan Microsoft Excell.

\section{HASIL DAN PEMBAHASAN}

\section{Waktu hilang karena tumpang tindih pengolahan tanah}

Waktu hilang merupakan variabel yang paling sulit dinilai dalam hubungannya dengan kapasitas lapang. Waktu lapang bisa hilang akibat pengolahan tanah yang tumpang tindih, slip pada roda traktor, serta pembelokan.

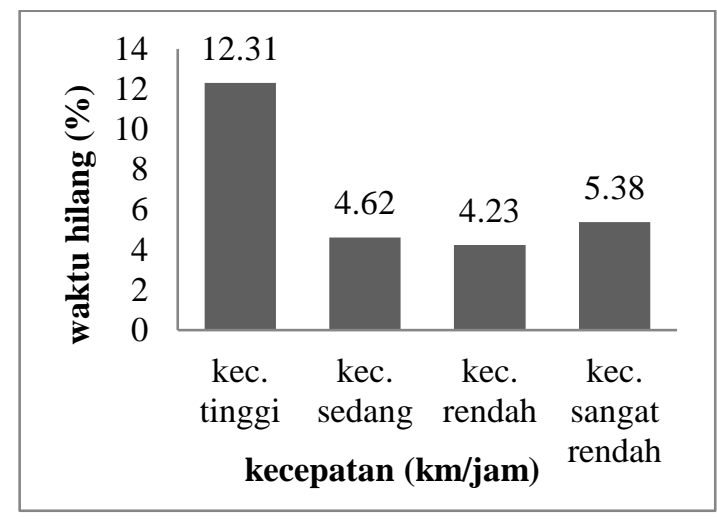

Gambar 1. Hasil perhitungan waktu hilang karena terjadi tumpang tindih pengolahan tanah dengan 1 bajak

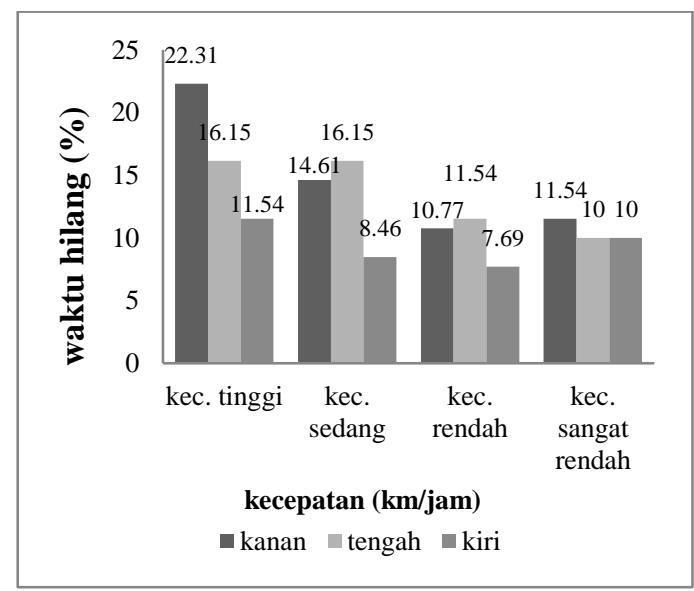

Gambar 2. Hasil perhitungan waktu hilang karena tumpang tindih pengolahan tanah dengan 3 bajak

Dari Gambar 1 dan 2, dapat dilihat bahwa rata-rata waktu hilang menggunakan tiga bajak lebih besar dibandingkan waktu hilang menggunakan satu bajak. Hal ini disebabkan karena 
traktor memiliki beban yang lebih besar pada pengolahan tanah menggunakan tiga bajak daripada satu bajak sehingga operator kesulitan dalam pengoprasian traktor dengan tiga bajak.

\section{Waktu hilang karena slip roda}

Slip roda ditentukan oleh jumlah putaran roda, jarak tempuh, diameter roda.

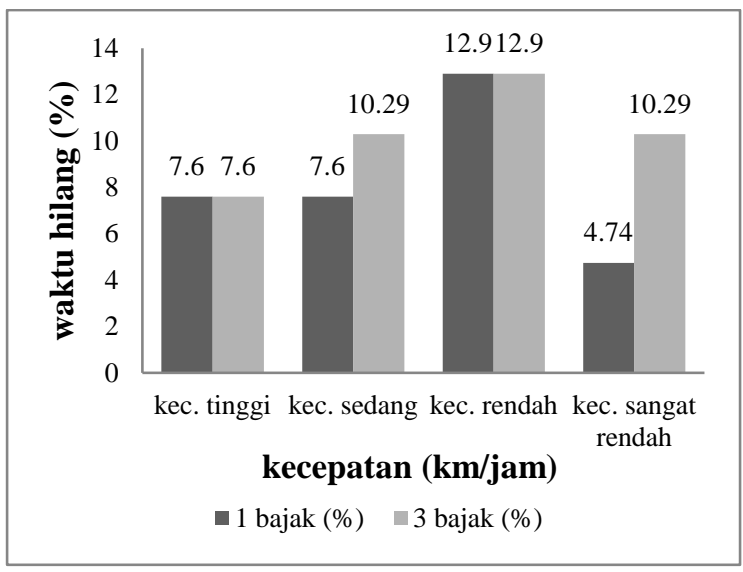

Gambar 3. Hasil perhitungan waktu hilang karena terjadinya slip roda

Perbandingan waktu hilang karena slip roda menggunakan satu bajak dan tiga bajak menunjukkan bahwa nilai rata-rata persentasi waktu hilang menggunakan tiga bajak lebih besar dibandingkan menggunakan satu bajak. selain disebabkan oleh kelengketan tanah pada roda lebih banyak dan jarak tempuh pengolahan tanah, juga disebabkan oleh beban pada traktor menggunakan tiga bajak lebih besar dari pada menggunakan satu bajak.

\section{Waktu hilang belok di ujung lapangan}

Waktu belok adalah waktu yang dibutuhkan bajak pada saat membelok pada akhir suatu lintasan sampai memasuki lintasan berikutnya. Kehilangan waktu pada saat belok di ujung lapangan ditentukaan oleh perbandingan antara waktu belok dan waktu total pengolahan tanah.

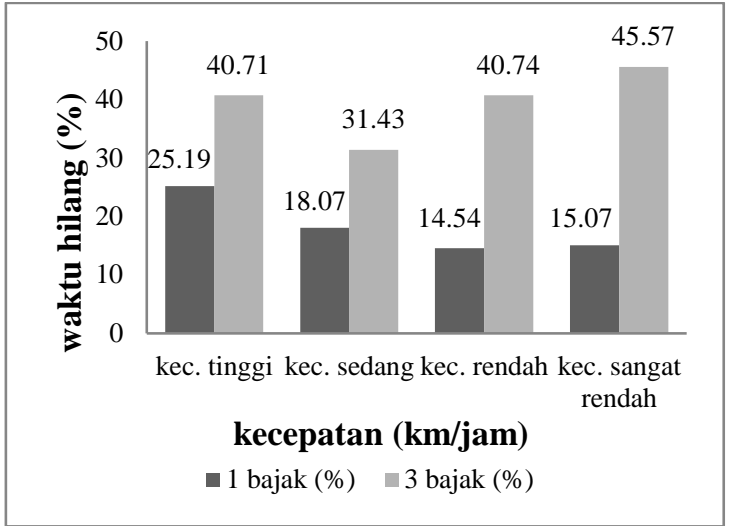

Gambar 4. Hasil perhitungan waktu hilang karena belok di ujung lapangan

Gambar 4 menunjukan bahwa perbandingan waktu hilang karena belok di ujung lapangan menggunakan tiga bajak rata-rata memiliki waktu hilang yang lebih banyak dibandingkan dengan menggunakan satu bajak karena beban mengolah tanah mengunakan tiga bajak lebih besar dibandingkan dengan satu bajak. Waktu hilang pengolahan dengan satu bajak dari kecepatan tinggi ke kecepatan rendah semakin kecil. Namun, dengan menggunakan tiga bajak terjadi sebaliknya, semakin rendah kecepatan, semakin tinggi waktu hilangnya. Hal ini disebabkan karena beban pada traktor. Dengan menggunakan satu bajak, karena beban traktor tidak terlalu besar dengan kecepatan yang semakin rendah akan mempercepat waktu belok. Sedangkan dengan menggunakan tiga bajak, beban yang dihasilkan akan semakin besar sehingga saat belok dengan menggunakan kecepatan yang semakin tinggi akan mepermudah atau mempercepat waktu belok.

\section{Kedalaman pembajakaan}

Kedalaman pembajakan diketahui dengan pengukuran pada lahan yang telah diolah dengan membenamkan alat ukur kedalam tanah dengan melihat nilai kedalamannya pada meteran sampai pada permukaan tanah. 


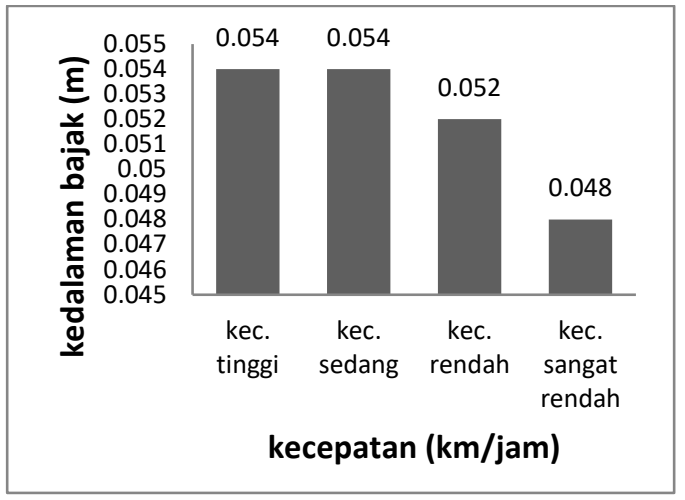

Gambar 5. Hasil pengukuran kedalaman pembajakan dengan satu bajak

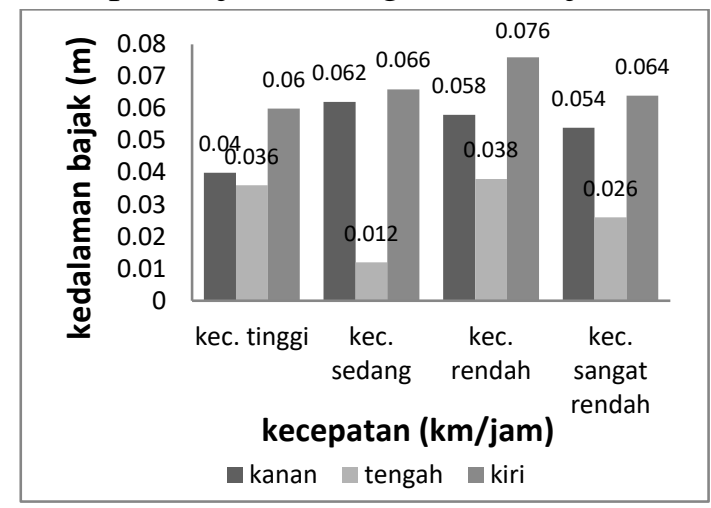

Gambar 6. Hasil pengukuran kedalaman pembajakan dengan tiga bajak

Gambar 5 dan 6 menunjukkan hasil kedalaman pembajakan dengan menggunakan tiga bajak lebih besar dibandingkan dengan menggunakan satu bajak. Hal ini disebabkan beban saat menggunakan tiga bajak lebih besar dari pada satu bajak, sehingga tekanan menggunakan tiga bajak lebih besar dari pada satu bajak.

\section{Efisiensi pengolahan tanah}

Efisiensi pengolahan tanah dipengaruhi oleh kapasitas kerja suatu alat. Kapasitas kerja alat didefinisikan sebagai suatu kemampuan kerja suatu alat atau mesin memberikan hasil (hektar, kilogram, liter) per satuan waktu. Jadi kapasitas kerja pengolahan tanah adalah berapa hektar kemampuan suatu alat dalam mengolah tanah per satuan waktu, sehingga satuannya adalah hektar per jam atau jam per hektar atau hektar per jam per HP traktor (Suastawa dkk, 2000). Kapasitas lapang suatu alat atau mesin dibagi menjadi dua, yaitu kapasitas lapang teoritis $(\mathrm{Kt})$ dan kapasitas lapang aktual (Ka).

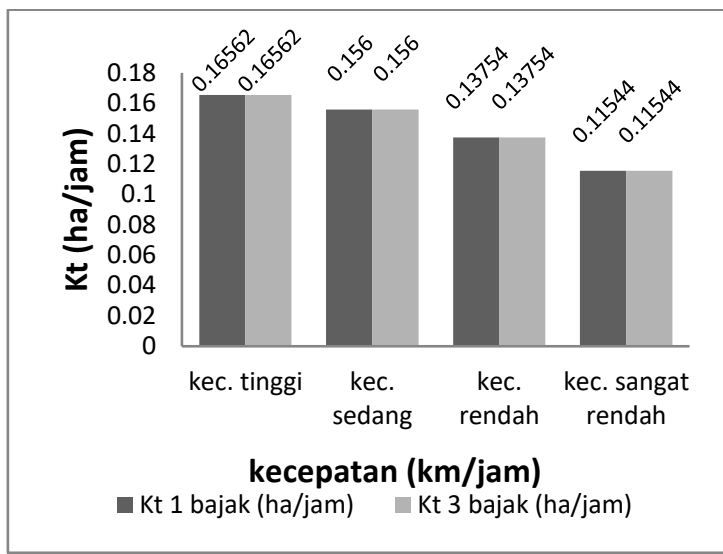

Gambar 7. Hasil perhitungan Kt pengolahan tanah

Nilai Kt pada pengolahan tanah dengan satu dan tiga bajak tidak berbeda pada masing-masing kecepatan. Hal ini disebabkan nilai kecepatan kerja dan lebar kerja pengolahan tanah yang merupakan faktor penentu kapasitas kerja teoritis tidak berbeda pada tiap kecepatan untuk satu dan tiga bajak.

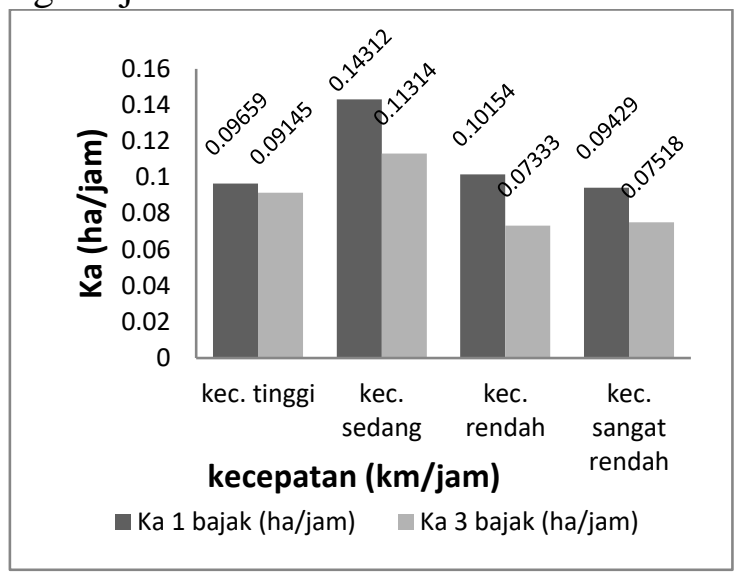

Gambar 8. Hasil perhitungan $\mathrm{Ka}$ pengolahan tanah

Nilai Ka pada pengolahan tanah menggunakan satu bajak lebih tinggi daripada pengolahan tanah menggunakan tiga bajak pada tiap kecepatan. Hal ini disebabkan waktu pengolahan tanah menggunakan satu bajak lebih singkat dibandingkan dengan menggunakan tiga bajak. Hal ini dikarenakan traktor memiliki beban yang lebih besar pada pengolahan tanah menggunakan tiga bajak daripada satu bajak. 
Nilai efisiensi lapang pengolahan tanah dipengaruhi oleh kapasitas lapang pengolahan tanah, karena efisiensi pengolahan tanah merupakan perbandingan antara kapasitas lapang aktual dengan kapasitas lapang teoritis yang dinyatakan dalam persen (\%).

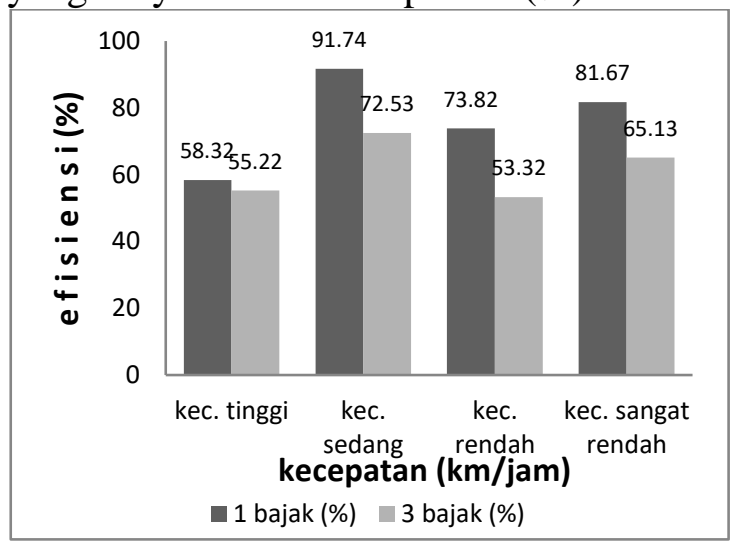

Gambar 9. Hasil perhitungan efisiensi pengolahan tanah

Nilai efisiensi pengolahan tanah dengan satu bajak lebih tinggi dibandingkan dengan pengolahan tanah menggunakan tiga bajak. Hal ini disebabkan beban pada traktor menggunakan tiga bajak lebih besar dari pada menggunakan satu bajak. Selain itu, waktu hilang pengolahan tanah dengan satu bajak lebih kecil dibandingkan dengan tiga bajak, sehingga efisiensi pengolahan tanah dengan satu bajak lebih tinggi dibandingkan dengan tiga bajak.

\section{Efektivitas Penyiangan}

Penyiangan termasuk pengendalian mekanis secara manual, yaitu dengan cara merusak sebagian atau seluruh gulma sampai terganggu pertumbuhannya atau mati sehingga tidak menganggu tanaman (Rukmana dkk, 1999). Pada penelitian ini, efisiensi pengolahan tanah ditentukan berdasarkan perbandingan antara gulma yang tercabut dengan alat dan gulma yang tercabut secara manual.

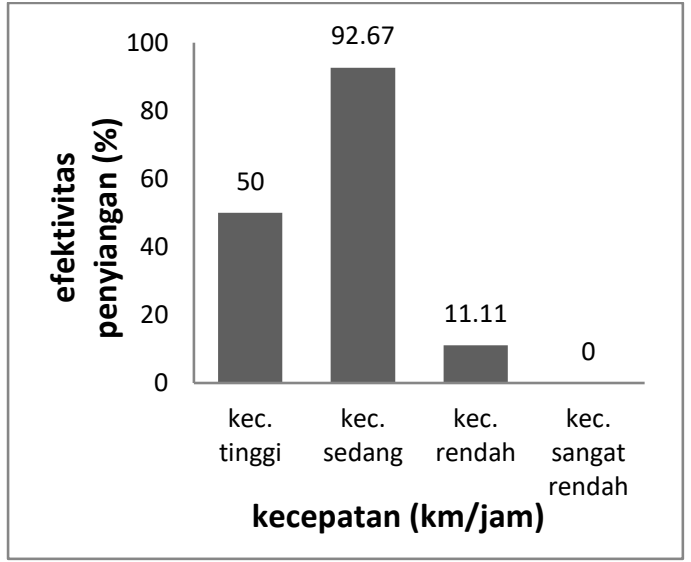

Gambar 10. Hasil perhitungan efektivitas penyiangan

Gambar 10 menunjukan bahwa jumlah gulma serta tingkat pertumbuhannya. Semakin tinggi kecepatan yang digunakan untuk penyiangan maka efektivitas penyiangan akan semakin tinggi, hal ini disebabkan jika kecepatan semakin tinggi, gulma akan lebih mudah terpotong atau terangkat. Traktor tangan roda empat yang digunakan dalam penelitian ini mencapai batas maksimun dalam penyiangan pada kecepataan sedang, sehingga pada kecepatan tinggi efektivitas penyiangan menurun.

\section{KESIMPULAN \& SARAN}

\section{Kesimpulan}

Berdasarkan hasil penelitian yang telah dilakukan dapat ditarik kesimpulan sebagai berikut:

1. Semakin rendah kecepatan, nilai kapasitas lapang teoritis (Kt) semakin rendah.

2. Nilai kapasitas lapang aktual (Ka) tertinggi terdapat pada kecepatan 6 $\mathrm{km} / \mathrm{jam}$, yaitu $0,14312 \mathrm{ha} / \mathrm{jam}$ untuk 1 bajak dan 0,11314 ha/jam untuk tiga bajak.

3. Waktu hilang tertinggi pada pengolahan tanah dengan tiga bajak pada kecepatan $4,44 \mathrm{~km} / \mathrm{jam}$ yaitu $45,57 \%$ dan terendah dengan satu bajak pada kecepatan 5,29 $\mathrm{km} / \mathrm{jam}$ yaitu $4,23 \%$.

4. Kedalaman pembajakan tertinggi pada kecepatan 5,29 km/jam pengolahan tanah dengan tiga bajak yaitu pada pada 
bajak sebelah kiri sebesar 0,076 $\mathrm{m}$ dan terendah pada kecepatan $6 \mathrm{~km} / \mathrm{jam}$ pada bajak tengah sebesar $0,012 \mathrm{~m}$.

5. Pengolahan tanah dengan kecepatan 6 $\mathrm{km} /$ jam memiliki efisiensi yang paling tinggi diantara kecepatan lainnya, baik pengolahan tanah dengan satu bajak maupun tiga bajak, masing-masing sebesar 91,74\% dan 72,53\%.

6. Pada efisiensi penyiangan, kecepatan 6 $\mathrm{km} / \mathrm{jam}$ memiliki efisiensi penyiangan paling tinggi dibandingkan kecepatan yang lain, yaitu sebesar 92,67 \% .

\section{Saran}

Saran yang dapat direkomendasikan adalah diperlukan penyempurnaan model traktor tangan roda empat agar lebih baik sehingga diperoleh hasil pengolahan tanah yang lebih baik, dapat mempersingkat waktu kerja, dan menekan kerugian waktu saat pengolahan tanah.

\section{DAFTAR PUSTAKA}

Akbar ARM, Pramudya B, Herodin S, Astika IW. 2004. Pemodelan Faktor Ergonomi terhadap Produktivitas Kerja pada Pengolahan Tanah Pertama Areal
Padi Sawah. Jurnal Keteknikan Pertanian. Vol. 18 No. 3: 178-190. Bogor.

Andrianto, T.T., Indarto, N. 2004. Budidaya dan Analisis Usaha Tani Buncis, Kacang Tanah, Kacang Tunggak. Yogyakarta: Absolut.

Rukmana dan Saputra. 1999. Gulma dan Teknik Pengendaliannya. Kanisius. Jakarta, dalam Sitompul, S.M. dan B. Guritno, 1995. Analisis Pertumbuhan Tanaman. Gadjah Mada University Press. Yogyakarta. 407 p.

Santoso, Andasuryani, Rinaldi S, Dede P. 2007. Modifikasi Rotary Tiller sebagai Implement pada Traktor Tangan. Jurnal Keteknikan Pertanian. Vol. 5. No. 1: 66.

Suastawa, I. N., W. Hermawan, dan E. N. Sembiring. 2000. Konstruksi dan Pengukuran KinerjaTraktor Pertanian. Teknik Pertanian. Fateta. IPB. Bogor. 